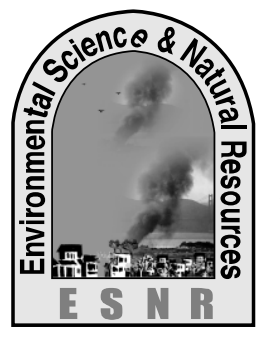

\title{
Investigation of Heavy Metal Contamination in Fishes from Passur River near the Sundarbans Mangroves of Bangladesh
}

\author{
M. S. Islam ${ }^{1 *}$, S. C. Shil ${ }^{1}$, M. H. Kabir ${ }^{1}$ and M. E. Hoq ${ }^{2}$ \\ ${ }^{1}$ Department of Environmental Science and Resource Management, Mawlana Bhashani Science and \\ Technology University, Tangail-1902, Bangladesh \\ ${ }^{2}$ Bangladesh Fisheries Research Institute, Mymensingh-2201, Bangladesh \\ *Corresponding author: islammstazu@yahoo.com
}

\begin{abstract}
The study was conducted to investigate the heavy metal contamination in fishes and shrimps from the Passur River near the world famous Sundarban mangroves located in the southwestern part of Bangladesh, during the period from January to June 2013. The fish (Liza parse) and shrimp (Penaeus monodon) samples were collected from two stations as St-1 (Katakhali-1 km upper from port areaupstream) and St-2 (Amtola-1 km lower from port area- downstream) monthly for three months in January (winter), March (pre monsoon) and May (Monsoon). Before analysis, a bit of muscle, the whole liver and two gill arches from each fish and shrimp were removed. Samples of tissues from each fish and shrimp were removed, weighed and dried. A microwave digestion system was used to prepare the samples for analysis. After digestion residue diluted with $25 \mathrm{ml} 2.5 \% \mathrm{HNO}_{3}$. The water used was deionized and distilled. The metal analyses of samples $(\mathrm{Cd}, \mathrm{Cr}, \mathrm{Cu}, \mathrm{Pb}$ and $\mathrm{Zn}$ ) were carried out by using UNICAM-929 atomic absorption spectrophotometer (AAS) in SGS Bangladesh Limited, Dhaka-1205, Bangladesh. Among the heavy metals studied $\mathrm{Cd}, \mathrm{Cr}, \mathrm{Cu}, \mathrm{Pb}$ and $\mathrm{Zn}$ were detected in fish and shrimp species were within acceptable limits by FAO standards. The results of this study indicated that a general absence of serious pollution in the Passur River is due to heavy metals; whereas the concentrations of elements found could mainly be attributed to geological sources. In this regard, to maintain the water and sediment qualities as well as the sound and safe aquatic life of the river need proper monitoring and management by the relevant authorities of the Government of Bangladesh.
\end{abstract}

Key words: Fish, Heavy metal, Passur river and Shrimp

\section{Introduction}

Heavy metals such as copper, iron, chromium and nickel are essential metals since they play an important role in the biological systems, whereas cadmium and lead are non-essential metals, as they are toxic, even in trace amounts (Fernandes et al., 2008). For the normal metabolism of the fish, the essential metals must be taken up from water, food or sediment (Canli and Atli, 2003). These essential metals can also produce toxic effects when the metal intake is excessively elevated (Tuzen, 2003). Studies on heavy metals in rivers, lakes, fish and sediments (Ozmen et al. 2004; Begum et al. 2005; Fernandes et al. 2008; Ozturk et al. 2008; Pote et al. 2008 and Praveena et al. 2008) have been a major environmental focus especially during the last decade. Sediments are important sinks for various pollutants like pesticides and heavy metals play a significant role in the remobilization of contaminants in aquatic systems under favorable conditions and in interactions between water and sediment (Rashed, 2011). Bangladesh is one of the most polluted countries, which currently holds 1,176 industries that discharge about 0.4 millions $\mathrm{m}^{3}$ of untreated waste to the rivers in a day (Rabbani and Sharif, 2005). The increasing urbanization and industrialization of Bangladesh have negative implications for water quality. Industrial effluents directly dispose into the rivers without any consideration of the environment (BCAS, 2004). Due to adverse effect of Farakka Barrage, most of the river's situation of Bangladesh is turning from bad to worse (Zaman et al., 1999).

Bangladesh has extensive water bodies that have a high potential for fisheries production (Mustafa and Brooks, 2009). Fisheries play an important role in the agrobased economics of Bangladesh by providing nutrition, increasing employment opportunities and earning foreign exchange. Fisheries sector contributed 4.43,
22.21 and $2.73 \%$ to the national GDP, agricultural GDP and foreign exchange earnings by exporting fish products, respectively in 2010-11. Fish is an important dietary animal protein source in human nutrition (Abbas et al., 2010). The aquatic environment governs fish life; hence water quality should be suitable for fish culture. The successful aquaculture depends on the quality of different water parameters (Rahman, 1992). The deterioration could be due to the release of easily oxidized industrial and municipal organic wastes. In such low DO state, no aquatic life can survive and thus the river reaches to a dying stage (Islam et al., 2012). Fish samples can be considered as one of the most significant indicators in freshwater ecosystems for the estimation of metal pollution level (Rashed, 2011). The commercial and edible species have been widely investigated in order to check for those hazardous to human health (Begum et al., 2005).

The aim of this study was investigate the heavy metal contamination in fish and shrimp species from the Mongla port area near the Sunderban mangrove, since the fish and shrimp are important components of the human diet in this area. The following objectives were carried out to complete the study successfully: (i) to determine the level of heavy metals in fish and shrimp species in the Passur River, and (ii) to evaluate the variation of heavy metals in fish and shrimp species.

\section{Materials and Methods}

\section{Study area}

The study was conducted at Passur River in Mongla Port area near the Sundarbans mangrove forest. The Mongla port area is located about $48 \mathrm{~km}$ south of Khulna city and developed initially about $18 \mathrm{~km}$ up at Chalna, which was opened for foreign vessels as an anchorage on 11 December 1950. The anchorage was shifted to Mongla in 1954 as the place could 
accommodate sea-going vessels with greater draughts. The port of Mongla had long retained its name Chalna. Mongla is situated on the confluence of the river Passur and Mongla at Mouza Selabunia of Rampul upazila in Bagerhat district. The duration of the study was six month from January to June 2013. South of Mongla upazila the river flows into the Sundarbans. The Passur is placed after the Meghna in size in the deltaic region. The river is joined by Mongla canal at about $32 \mathrm{~km}$ south from Chalna.

\section{Sample collection}

In this study one fish (Liza parse) and one shrimp ( $P$. monodon) species were collected from two locations upstream (Katakhali) and downstream (Amtola) from the Passur river at port area. Same species of fish and shrimp samples were collected directly from the fisherman monthly for three months (January, March and May). Three months are considered as winter, premonsoon and monsoon respectively. The weight values of each fish and shrimp samples were measured. The fish (150 gm) and shrimp (150 gm) samples were collected from each sampling stations for analysis. The samples were brought to the laboratory with ice box. Fish and shrimp samples were kept at freeze for preservation and to avoid further contamination until analysis.

\section{Sample analysis}

The fish and shrimp samples were analysed in the Central laboratory of Societe Genrale de Surveillance (SGS), (Food Laboratory) Kawran Bazar, Dhaka-1205. In this study, fish and shrimp samples were collected from the sampling locations, at Passur River, Mongla port area. Fish samples were kept at freeze until analysis. Before analysis, a bit of muscle, the whole liver and two gill arches from each fish and shrimp were removed. Samples of tissues from each fish and shrimp were weighed and dried. A microwave digestion system (CEM-MDS 2000) was used to prepare the samples for analysis. The advantage of microwave digestion against the classical method are the shorter time, less consumption of acid and keeping volatile compounds in the solution (Krushevska et al., 1993; Gulmini et al., 1994; Sures et al., 1995). After digestion, the residues diluted to $25 \mathrm{ml}$ with $2.5 \%$ of $\mathrm{HNO}_{3}$. Instrument calibrated standard solutions were prepared from commercial materials. The water used was deionized and distilled. The metal analyses of samples $(\mathrm{Cd}, \mathrm{Cr}, \mathrm{Cu}, \mathrm{Pb}$ and $\mathrm{Zn}$ ) were carried out by using UNICAM-929 atomic absorption spectrophotometer (AAS). The fish and shrimp species were analyses by AOAC $18^{\text {th }}$ Edition.

\section{Results and Discussion}

The concentrations of heavy metals in muscle, liver and gills of the fish samples are given in Table 1 and 2 . The fish (Liza parse) represent the metal $\mathrm{Cd}(<0.05)$ both in winter and pre-monsoon season both of Katakhali and Amtola station respectively. In the monsoon season, $\mathrm{Cd}$ represents 0.013 and $0.026(\mathrm{mg} / \mathrm{kg})$ in the Katakhali and Amtola station respectively. Cr represents 0.196 and 0.19 in winter, 0.198 and 0.555 in pre-monsoon, and 0.965 and $0.165(\mathrm{mg} / \mathrm{kg})$ in monsoon season in the Katakhali and Amtola station respectively. $\mathrm{Cu}$ represents 1.26 and 0.73 in winter, 0.536 and 0.523 in pre-monsoon, 0.902 and $0.707(\mathrm{mg} / \mathrm{kg})$ in monsoon season in the Katakhali and Amtola station respectively. $\mathrm{Pb}$ represents $(<0.05)$ and 0.22 in winter, 0.193 and0.361 in pre-monsoon, 0.104 and $0.093(\mathrm{mg} / \mathrm{kg})$ in monsoon season in the Katakhali and Amtola station respectively. $\mathrm{Zn}$ represents 8.32 and 12.54 in winters, 7.734 and 7.851 in pre-monsoon, 9.4117 and 9.169 $(\mathrm{mg} / \mathrm{kg})$ in monsoon season in the Katakhali and Amtola station respectively (Table 1). All the values of metal $(\mathrm{Cd}, \mathrm{Cr}, \mathrm{Cu}$, ) is lower than the permissible level (Table 1). In the pre-monsoon season $\mathrm{Pb}$ exceed the permissible level (Table 1). The values of $\mathrm{Zn}$ are much higher than the permissible level in the winter, premonsoon and monsoon season respectively (Table 1).

Table 1. The heavy metal concentrations of fish (Liza parse) species from the Passur River, Mongla port

\begin{tabular}{llccccc}
\hline Season & Sampling & \multicolumn{3}{c}{ Heavy metals (mg/kg) } \\
\cline { 3 - 7 } & station & Cd & Cr & Cu & Pb & Zn \\
\hline \multirow{2}{*}{ Winter } & Katakhali & $<0.05$ & 0.196 & 1.260 & $<0.050$ & 8.320 \\
\multirow{3}{*}{ Pre-Monsoon } & Amtola & $<0.05$ & 0.190 & 0.730 & 0.220 & 12.54 \\
\multirow{3}{*}{ Monsoon } & Katakhali & $<0.05$ & 0.198 & 0.536 & 0.193 & 7.734 \\
& Amtola & $<0.05$ & 0.555 & 0.523 & 0.361 & 7.851 \\
\multirow{2}{*}{ Standard (FAO, 1984) } & Katakhali & 0.013 & 0.965 & 0.902 & 0.104 & 9.417 \\
\hline
\end{tabular}

The Shrimp (Penaeus monodon) represents the metal $\mathrm{Cd}(<0.05)$ and 0.10 in winter, 0.067 and $<0.05$ in premonsoon season, 0.033 and $0.043(\mathrm{mg} / \mathrm{kg})$ in monsoon season both of Katakhali and Amtola station respectively. $\mathrm{Cr}$ represents 0.29 and 0.39 in winter, 0.244 and 1.450 in pre-monsoon, and 0.023 and 0.780 $(\mathrm{mg} / \mathrm{kg})$ in monsoon in the Katakhali and Amtola station respectively. $\mathrm{Cu}$ represents 4.40 and 8.64 in winter, 17.437 and 16.439 in pre-monsoon, 9.270 and $13.335(\mathrm{mg} / \mathrm{kg})$ in monsoon season in the Katakhali and Amtola station respectively. $\mathrm{Pb}$ represents 0.20 and 0.22 in winter, 0.082 and 0.123 in pre-monsoon, 0.045 and $0.081(\mathrm{mg} / \mathrm{kg})$ in monsoon season in the Katakhali and Amtola station respectively. Zn represents 11.49 and 34.34 in winter, 13.353 and 13.865 in pre-monsoon, 9.689 and $11.765(\mathrm{mg} / \mathrm{kg})$ in monsoon season in the 
Katakhali and Amtola station respectively. All the values of metal $(\mathrm{Cd}, \mathrm{Cu}, \mathrm{Pb})$ is lower than the permissible level. In the pre-monsoon period $\mathrm{Cr}$ exceed the permissible level (Table 2). The values of $\mathrm{Zn}$ are much higher than the permissible level in the winter, pre-monsoon and monsoon season respectively (Table 2).
Among the heavy metals studied $\mathrm{Cd}, \mathrm{Cr}, \mathrm{Cu} \mathrm{Pb}$ and $\mathrm{Zn}$ were detected in fish and shrimp species were within acceptable limits by FAO standards. The results of the study indicated that a general absence of serious heavy metals pollution in the Passur River; whereas the concentrations of elements found could mainly be attributed to geological sources.

Table 2. The heavy metal concentrations of shrimp (Penaeus monodon) species from the Passur river, Mongla port

\begin{tabular}{|c|c|c|c|c|c|c|}
\hline \multirow[t]{2}{*}{ Season } & \multirow{2}{*}{$\begin{array}{l}\text { Sampling } \\
\text { station }\end{array}$} & \multicolumn{5}{|c|}{ Heavy metals (mg/kg) } \\
\hline & & Cd & $\mathrm{Cr}$ & $\mathbf{C u}$ & $\mathbf{P b}$ & $\mathbf{Z n}$ \\
\hline \multirow[t]{2}{*}{ Winter } & Katakhali & $<0.05$ & 0.29 & 4.40 & 0.20 & 11.49 \\
\hline & Amtola & 0.10 & 0.39 & 8.64 & 0.22 & 34.34 \\
\hline \multirow[t]{2}{*}{ Pre-Monsoon } & Katakhali & 0.067 & 0.244 & 17.437 & 0.082 & 13.353 \\
\hline & Amtola & $<0.05$ & 1.450 & 16.439 & 0.123 & 13.865 \\
\hline \multirow[t]{2}{*}{ Monsoon } & Katakhali & 0.033 & 0.023 & 9.270 & 0.045 & 9.689 \\
\hline & Amtola & 0.043 & 0.780 & 13.335 & 0.081 & 11.765 \\
\hline \multicolumn{2}{|c|}{ Standard (FAO, 1984) } & 0.5 & 1.00 & 30.00 & 0.30 & 30.00 \\
\hline
\end{tabular}

A comparative study between the heavy metal concentrations of fish and shrimp species of the Passur river and other rivers such as Buriganga and Turag river was also performed to depict the status of heavy metals bioaccumulation in fishes of Passur river in relation to others (Table 3). The study depicted that the $\mathrm{Pb}$ contamination of the Passur and Turag rivers were within standard level where the Buriganga river showed higher level of $\mathrm{Pb}$ contamination that exceed the standard level $0.30 \mathrm{mg} / \mathrm{kg}$ as set by FAO (1984) for aquatic organisms. The Buriganga river fish was highly contaminated by $\mathrm{Cd}$ and $\mathrm{Cr}$ pollution, exceed the standard level 0.5 and $1.0 \mathrm{mg} / \mathrm{kg}$ (FAO, 1984), respectively than Passur and Turag river. The highest and lowest $\mathrm{Cu}$ was found in Passur and Turag river, respectively, while all of the rivers were within the standard level $30 \mathrm{mg} / \mathrm{kg}$, as per guidelines by FAO (1984). Although, the bioaccumulation of heavy metals depend on the dose, duration, route of exposure and individual species organism factors (Timbrell, 2002), from the overall analysis, it can be stated that the heavy metals contamination in fishes of Buriganga river is worse than the others.

Table 3. Comparison of heavy metal concentrations $(\mathrm{mg} / \mathrm{kg})$ of fish and shrimp species among the Passur, Buriganga and Turag river.

\begin{tabular}{|c|c|c|c|c|c|c|c|c|c|c|c|c|}
\hline \multirow[t]{2}{*}{ Species } & \multicolumn{4}{|c|}{$\begin{array}{l}\text { Passur River } \\
\text { (Present study) }\end{array}$} & \multicolumn{4}{|c|}{$\begin{array}{c}\text { Buriganga River } \\
\text { (Ahmad et al., 2010) }\end{array}$} & \multicolumn{4}{|c|}{$\begin{array}{c}\text { Turag River } \\
\text { (Rezuana et al., 2015) }\end{array}$} \\
\hline & $\mathrm{Pd}$ & $\mathrm{Cd}$ & $\mathrm{Cr}$ & $\mathrm{Cu}$ & $\mathrm{Pd}$ & $\mathrm{Cd}$ & $\mathrm{Cr}$ & $\mathrm{Cu}$ & $\mathrm{Pd}$ & $\mathrm{Cd}$ & $\mathrm{Cr}$ & $\mathrm{Cu}$ \\
\hline L. parse & 0.17 & 0.04 & 0.38 & 0.78 & $\mathrm{Nt}$ & $\mathrm{Nt}$ & $\mathrm{Nt}$ & $\mathrm{Nt}$ & $\mathrm{Nt}$ & $\mathrm{Nt}$ & $\mathrm{Nt}$ & $\mathrm{Nt}$ \\
\hline P. monodon & 0.13 & 0.05 & 0.53 & 11.59 & $\mathrm{Nt}$ & $\mathrm{Nt}$ & $\mathrm{Nt}$ & $\mathrm{Nt}$ & $\mathrm{Nt}$ & $\mathrm{Nt}$ & $\mathrm{Nt}$ & $\mathrm{Nt}$ \\
\hline C. punctatus & $\mathrm{Nt}$ & $\mathrm{Nt}$ & $\mathrm{Nt}$ & $\mathrm{Nt}$ & 9.11 & 0.88 & 5.66 & 5.31 & 0.03 & 0.006 & 0.25 & 0.44 \\
\hline G. giuris & $\mathrm{Nt}$ & $\mathrm{Nt}$ & $\mathrm{Nt}$ & $\mathrm{Nt}$ & 9.91 & 0.87 & 6.42 & 5.03 & 0.06 & 0.002 & 0.38 & 0.62 \\
\hline
\end{tabular}

Note: $C$. punctatus $=$ Channa punctatus, . . giuris $=$ Glossogobius giuris, $\mathrm{Nt}=\mathrm{Not}$ tested.

\section{Conclusions}

The concentrations of heavy metal elements $(\mathrm{Cu}, \mathrm{Zn}, \mathrm{Fe}$ and $\mathrm{Cr}$ ) were found from water much lower than the permissible level. The concentrations of five heavy metals $(\mathrm{Cr}, \mathrm{Cu}, \mathrm{Ni}, \mathrm{Pb}$, and $\mathrm{Fe})$ were identified in the sediment sample. The values of $\mathrm{Fe}$ were found at 23481.61 to $15339.4 \mathrm{mg} / \mathrm{kg}$. Other metals value is much lower. Among the heavy metals studied $\mathrm{Cd}, \mathrm{Cr}, \mathrm{Cu}, \mathrm{Pb}$ and $\mathrm{Zn}$ were detected in fish and shrimp species were within acceptable limits by FAO standards. The results of this study indicated that a general absence of serious pollution in the Passur River is due to heavy metals; whereas the concentrations of elements found could mainly be attributed to geological sources. According to research findings following recommendations were made for the management of water quality, sediment, fish and shrimp species of Mongla port area and adjacent rivers. Make a new regulation for Passur and surrounding rivers; Creating a new authority; Initiate intensive research; Water quality monitoring; Planning; Coordination activities; Illegal encroacher's evacuation; Awareness building and sustainable port management; Legislation on dumping of industrial waste into the river should be established as well as some mitigation measures should be taken.

\section{References}

Abbas, S.; Ahmed, I.; Salim, M. and Rehman, K. 2010. Comparative effects of fertilization and supplementary feed on growth performance of three fish species. International Journal of Agriculture and Biology, 12: 276-280. 
BCAS (Bangladesh Centre for Advanced Studies). 2004. The state of Bangladeshi water, series 5. Bangladesh Centre for Advanced Studies. Dhaka. Bangladesh.

Begum, A.; Amin, M. N.; Kaneco, S. and Ohta, K. 2005. Selected elemental composition of the muscle tissue of three species of fish, Tilapia nilotica, Cirrhina mrigala and Clarius batrachus from the fresh water Dhanmondi Lake in Bangladesh. Food Chemistry, 93: 439-443.

Canli, M. and Atli, G. 2003. The relationships between heavy metal $(\mathrm{Cd}, \mathrm{Cr}, \mathrm{Cu}, \mathrm{Fe}, \mathrm{Pb}, \mathrm{Zn})$ levels and the size of six mediterranean fish species. Environmental Pollution, 121: 129-136.

FAO/WHO (Food and Agricultural Organization/ World Health Organization). 1984. List of maximum levels recommended for contaminants by the Joint FAO/WHO Codex Alimentarius Commission. Second Series. CAC/FAL, Rome, 3: $1-8$.

Fernandes, C.; Fontaínhas-Fernandes, A.; Cabral, D. and Salgado, M. A. 2008. Heavy metals in water, sediment and tissues of Liza saliens from Esmoriz-Paramos lagoon, Portugal. Environmental Monitoring Assessment, 136: 267275.

Gulmini, M.; Ostacoli, G. and Zelano, V. 1994. Comparison between microwave and conventional heating procedures in Tessier's extractions of calcium, copper, iron and manganese in a lagoon sediment. Analyst, 119: 2075-2080.

Krushevska, A.; Barnes, M. R. and Amarasiriwaradena, C. 1993. Decomposition of biological samples for inductively coupled plasma atomic emission spectrometry using an open focused microwave digestion system. Analyst, 118: 1175-1181.

Mustafa, M. G. and Brooks, A. C. 2009. A comparative study of two seasonal flood plain aquaculture systems in Bangladesh. Water Policy, 11(1): 6979.

Ozmen, H.; Kulahçi, F.; Çukurovali, A. and Dogru, M. 2004. Concentrations of heavy metal and radioactivity in surface water and sediment of Hazar Lake (Elazıg, Turkey). Chemosphere, 55: 401-408.
Ozturk, M.; Ozozen, G.; Minareci, O. and Minareci, E. 2008. Determination of heavy metals in of fishes, water and sediment from the Demirkopru Dam Lake (Turkey). Journal of Applied Biological Sciences, 2(3): 99-104.

Pote, J.; Haller, L.; Loizeau, J. L.; Bravo, A. G.; Sastre, V. and Wildi, W. 2008. Effects of a sewage treatment plant outlet pipe extension on the distribution of contaminants in the sediments of the Bay of Vidy, Lake Geneva, Switzerland. Bioresource Technology, 99: 7122-7131.

Praveena, S. M.; Radojevic, M.; Abdullah, M. H. and Aris, A. Z. 2008. Application of sediment quality guidelines in the assessment of mangrove surface sediment in Mengkabong lagoon, Sabah, Malaysia. Iranian Journal of Environmental Health Science Engineering, 5 (1): 35-42.

Rabbani, G. and Sharif, M. I. 2005. Dhaka City, State of Environment (SoE) 2005. UNEP in collaboration with BCAS and DoE, pp. 40.

Rahman, M. S. 1992. Water quality management in aquaculture. BRAC Prokashana, Bangladesh, p. 84.

Rashed, M. N. 2011. Monitoring of environmental heavy metals in fish from Nasser Lake. Environmental International, 27: 27-33.

Sures, B.; Taraschewski, H. and Haug, C. 1995. Determination of trace metals $(\mathrm{Cd}, \mathrm{Pb})$ in fish by electro thermal atomic absorption spectrometry after microwave digestion. Analytical Chemistry Acta, 311: 135-139.

Timbrell, J. 2002. Introduction to toxicology. $3^{\text {rd }}$ edition. Taylor and Francis, 11 new fetter lane, London. 57-58 pp.

Tuzen, M. 2003. Determination of heavy metals in fish samples of the Mid Dam Lake Black Sea (Turkey) by graphite furnace atomic absorption spectrometry. Food Chemistry, 80: 119-123.

Zaman, M. W.; Mokhlesh, R. M. and Zakir, H. M. 1999. Assessment of drought and surface water pollution in some irrigated areas of Nawabganj. Bangladesh Agricultural University Research Progress, 10: 48-57. 